\title{
Morphological Analysis on the Kalopanax pictus (Araliaceae) of Korean Populations
}

\author{
Sang Duk Jung*, Jung Hee Hong, Kyung Hwan Bang ${ }^{1}$ and Man Kyu Huh ${ }^{2}$ \\ Department of Biology, Pusan National University, Busan 609-735 \\ ${ }^{1}$ Division of Ginseng \& Medicinal Crops, National Institute of Crop Science, RDA, Suwon 441-857 \\ ${ }^{2}$ Department of Molecular Biology, Dongeui University, Busan 614-714
}

Received February 2, 2004 / Accepted April 17, 2004

\begin{abstract}
Morphological characteristics of Kalopanox pictus Nakai were studied to examine population differentiation of this species. Based on a phenogram of using 23 morphological characteristics, differentiation of regions were distinct. Collections of 138 specimens from nine populations served as operational taxonomic unit (OTU's) were examined for phenotypic similarity and morphological variation using clustering (Ward's minimum variance method) and principal component analysis (PCA). The first three principal components were responsible for $77.0 \%$ of the total variance. Principal component 1 explained $52 \%$ of the total variance and was contributed to by the number of palmately parted, the number of pinnately lobed, and width between two lateral lobe apex.
\end{abstract}

Key words - Morphological characteristics, Kalopanox pictus, phenogram

Morphological differentiation of species within their geographic distribution has been of considerable interest in the study of the evolution of species [17]. Morphological data from variables measured on a continuous scale are important in generating and testing evolutionary hypotheses and taxonomic hierarchies. Divergence among populations may occur as a result of microevolutionary changes in isolated populations in different nature in time. These changes in isolated populations in different environments produce individuals with different ecological tolerances to physical factors, resulting in the differentiation of divergence ecotypes. The actual geographical distribution of a species may be reflective of these changes over geological time. Differentiation between populations has received much attention in recent years using different approaches and many distinct taxa $[1,2,13]$.

The genus Kalopanox consists of one species, Kalopanox pictus (Araliaceae) which distributes throughout the world [7]. The species is distributed in temperate regions, with centers of diversity in East Asia. Typical populations are small and distributed in patches. K. pictus can be classified as a narrow habitat species because it is usually found on subsites of several Korean mountains, at elevations of 300 $400 \mathrm{~m}$. This species is long-lived perennial and has yellowgreen flowers [15]. The species is a polygamo-monoecious diploid species $(2 n=48)$, being predominantly out-crossed

*Corresponding author

Tel : +82-51-510-2263, Fax : +82-581-2962

E-mail : plantjeong@hanmail.net via wind-pollination [6,7]. Although plants grow high in the mountains on fertile soil, they are also extensively cultivated as a medicinal muscle relaxant. $K$. pictus is also an economically important for it stems, which historically were used for wooden shoes with clogs. Household goods are also valued because of the figured heartwood.

Until recently, much of the Korean forest has been disturbed by the cutting of trees and shrubs for firewood in rural areas[3,4]. Most sites are now being revegetated both naturally and artificially[4]. Although it is important to gain knowledge of the genetic variation for conservation purposes, detailed information on the level and distribution of this variation, as well as population structure, are not available for most woody taxa in Korea [3].

As $K$. pictus has been domesticated from wild relatives, it is expected that valuable cultivars may be found in these cultivators [5]. For a better characterisation and comparison of $K$. pictus germplasm diversity available in Korea, it is vital to use a morphological approach of population differences of this germplasm from wild populations.

Although there is much interesting the medicine and economic, only a handful of studies do not have explored basic of the population biology and ecology of $K$. pictus.

Consequently, there is a need to study the investigation of the nature to better understand the morphological characteristic of Korean $K$. pictus species. The objective of this paper is to; 1) compare the differentiation of $K$. pictus, 2) determine the overall geographical distribution patterns for the Korean species, and analyse morphological variation within and among Korean populations. 


\section{Materials and Methods}

\section{Collecting sites}

Samples of K. pictus were collected from nine populations in Korea. Table 1 lists the collection sites used in this study, along with three-letter abbreviations, and population sizes.

\section{Morphological characteristics}

The measurements of quantitative characters and observation of qualitative characters were taken on each of total individuals directly from their natural habitats from

Table 1. Localities for populations of K. pictus as source for morphological analyses

\begin{tabular}{llc}
\hline Code & Localities & Sample size \\
\hline UNI & Uongyang-gun, Gyeongsangnam-do & 17 \\
SAC & Sacheon-si, Gyeongsangnam-do & 16 \\
BUS & Goijeong-gu, Busan-si & 10 \\
DAM & Damyang-gun, Cheonranam-do & 20 \\
SAM & Samcheok-si, Gangwon-do & 16 \\
DAN & Danyang-gun, Chungcheongbuk-do & 15 \\
CHE & Cheongyang-gun, Chungcheongbuk-do & 12 \\
PAN & Pyuangchang-gun, Gangwon-do & 17 \\
GAC & Gacheon-si, Gyeonggi-do & 15 \\
\hline
\end{tabular}

during 2002 and 2003. Table 2 was shown lists of the morphological characteristics. The measurements made on plants were arranged in a data matrix indicating the means of plant characteristics for each population.

\section{Data analysis}

The main trends in variation between localities (populations) were summarized using univariate and multivariate analyses. Measurements of each particular trait were compared using one-way analysis of variance (ANOVA) with site of origin as a factor. Whenever a significant difference was found $(P<0.05)$, multiple comparison tests were performed fellowing SYSTAT procedures [14]. Bartlett's test was applied to test the homogeneity of variance [18] and transformations of variables were performed when data were not homoscedastic. For those variables in which transformations were enable to make the data meet the assumptions of ANOVA, we used a non-parametric method: the Kruskal-Wallis test, analogous to a single classification ANOVA [18].

Pearson correlation coefficients were calculated using the Statistical Analysis System [18] to determine correlations between morphological characteristics.

Table 2. List of 23 descriptive characteristics used in the morphological analysis

\begin{tabular}{llc}
\hline Acronym & Characteristic derivation & Unit or Category \\
\hline LOL & Number of lobe of leaf & ea \\
ACL & Angel of central lobe of leaf & degree \\
AP1 & Angel of first palmatified & degree \\
AP2 & Angel of second palmatified & degree \\
AP3 & Angel of 3rd palmatified & $\mathrm{mm}$ \\
WIL & Width of leaf (maximum) & $\mathrm{mm}$ \\
WML & Width between both first lobe apex (middle) & $\mathrm{mm}$ \\
WSL & Width between both 3rd lobe apex (minimum) & $\mathrm{mm}$ \\
LEL & Length of leaf & ratio \\
LTR & Rate of length/width (leaf) & $\mathrm{mm}$ \\
LCA & Length from basal sinus to central lobe apex & $\mathrm{mm}$ \\
LSA & Length from basal sinus to second lobe apex & $\mathrm{mm}$ \\
L3A & Length from basal sinus to 3rd lobe apex & $\mathrm{mm}$ \\
L4A & Length from basal sinus to 4th lobe apex & $\mathrm{mm}$ \\
MAG & Major groove of leaf & $\mathrm{mm}$ \\
MMG & Middle groove of leaf & $\mathrm{mm}$ \\
MIG & Minor groove of leaf & ea \\
NS1 & Number of serrulate at palmatified (1st margin) & ea \\
NS2 & Number of serrulate at palmatified (2nd margin) & ea \\
NS3 & Number of serrulate at palmatified (3rd margin) & ea \\
NS4 & Number of serrulate at palmatified (4th margin) & ea \\
NS5 & Number of serrulate at palmatified (5th margin) & ea \\
NS6 & Number of serrulate at palmatified (6th margin) & \\
\hline
\end{tabular}


Multivariate principal component analyses (PCAs) were conducted to detect differences among populations considering several characters simultaneously of variances using the Statistical Analysis System [18], and nine populations were used in this analyses. The data were standardized for each characteristic, with the raw data matrix transformed such that each characteristic had a mean of zero as a standard deviation [14]. The first three principle components were extracted by the PCA analyses. Pair-group analysis was utilized using an unweighted method (UPGMA) of agglomerating clustering based an Euclidian distance similarity matrix [14]. This cluster analysis was performed with morphological phenogram among populations based on quantitative variation [11].

\section{Results}

The major morphological characteristics of $K$. pictus which can be used as identification keys are presented in Table 2. Our analysis of variance, calculated from 23 morphological characteristics in each population, showed a slight heterogeneity of variance. For example, thirteen characteristic values were homoscedastic, of which ten values departed significantly from zero $(\mathrm{P}<0.05)$. The number of lobe of leaf (LOL) were shown a significant difference among nine populations $(\mathrm{P}<0.05)$ (Table 4$)$. The length from basal sinus to centrol lobe apex (LCA) has the highly significant positive correlations with the length of from basal sinus to second lobe apex (LSA), 3rd lobe apex (L3A), and 4th lobe apex (L4A).

The multivariate principal component analyses (PCAs) were performed based on the 23 morphological characteristics (Table 3). The first three principal component were responsible for $77.0 \%$ of the variance. Principal component 1 explained $52 \%$ of the total variance and was contributed to by the number of palmately parted, the number of pinnatedly lobed, and width between two lateral lobe apex. The second component accounts for $12.2 \%$ of the total variation and is mostly concerned with length of leaf (LEL and LTR).

In the two-dimensional plot constructed based on the morphological data derived from the PCA (Fig. 1), all the 23 characteristics are clearly separated into five or six classes. L3A, L4A, LCA, AP1, AP2, AP3, and ACL are classified one group. NS2 and NS3 are also classified one group. LOL, MAG, and NS1 are consisted of one group. WIL, NS5, and NS6 are same trend. LEL, NS4, MIG, MMG, WML, and LSA are formed a long ellipse. LTR showed a

Table 3. Testing the significance of differences among populations

\begin{tabular}{lrrrrl}
\hline Acronym & Mean + SE & SD & $F$ & $t$ & $P=0.05$ \\
\hline LOL & $6.73 \pm 0.70$ & 3.18 & 4.83 & 4.83 & $P<0.05$ \\
ACL & $50.68 \pm 1.06$ & 3.24 & 5.29 & 1.51 & $P>0.05$ \\
AP1 & $40.14 \pm 0.81$ & 1.51 & 10.13 & 2.68 & $P>0.05$ \\
AP2 & $50.13 \pm 1.21$ & 0.16 & 12.016 & 1.48 & $P>0.05$ \\
AP3 & $45.65 \pm 0.91$ & 1.84 & 1.84 & 2.10 & $P>0.05$ \\
WIL & $143.06 \pm 4.17$ & 10.21 & 2.06 & 0.78 & $P>0.05$ \\
WML & $137.06 \pm 3.80$ & 7.44 & 2.34 & 1.21 & $P>0.05$ \\
WSL & $67.23 \pm 2.09$ & 4.25 & 2.56 & 1.49 & $P>0.05$ \\
LEL & $164.22 \pm 3.51$ & 11.24 & 1.69 & 2.55 & $P>0.05$ \\
LTR & $1.14 \pm 0.03$ & 0.10 & 2.28 & $P>0.05$ \\
LCA & $72.40 \pm 5.47$ & 12.23 & 3.22 & 4.56 & $P<0.05$ \\
LSA & $56.20 \pm 4.72$ & 7.30 & 4.11 & 3.65 & $P<0.05$ \\
L3A & $40.51 \pm 3.75$ & 5.42 & 3.36 & 4.91 & $P<0.05$ \\
L4A & $27.66 \pm 3.20$ & 5.37 & 3.45 & 0.51 & $P<0.05$ \\
MAG & $89.40 \pm 3.48$ & 0.39 & 2.18 & 1.32 & $P>0.05$ \\
MMG & $60.30 \pm 4.93$ & 0.45 & 3.25 & 4.23 & $P>0.05$ \\
MIG & $42.29 \pm 0.83$ & 1.85 & 1.92 & 2.17 & $P<0.05$ \\
NS1 & $20.15 \pm 1.55$ & 1.34 & 2.43 & 0.37 & $P>0.05$ \\
NS2 & $17.11 \pm 0.26$ & 1.65 & 1.37 & 2.73 & $P>0.05$ \\
NS3 & $13.03 \pm 1.10$ & 1.48 & 2.87 & 2.67 & $P<0.05$ \\
NS4 & $13.38 \pm 1.30$ & 1.53 & 2.12 & 2.96 & $P<0.05$ \\
NS5 & $5.90 \pm 0.91$ & 1.37 & 3.65 & 6.45 & $P<0.05$ \\
NS6 & $48.20 \pm 2.20$ & & & $P<0.05$ \\
\hline
\end{tabular}




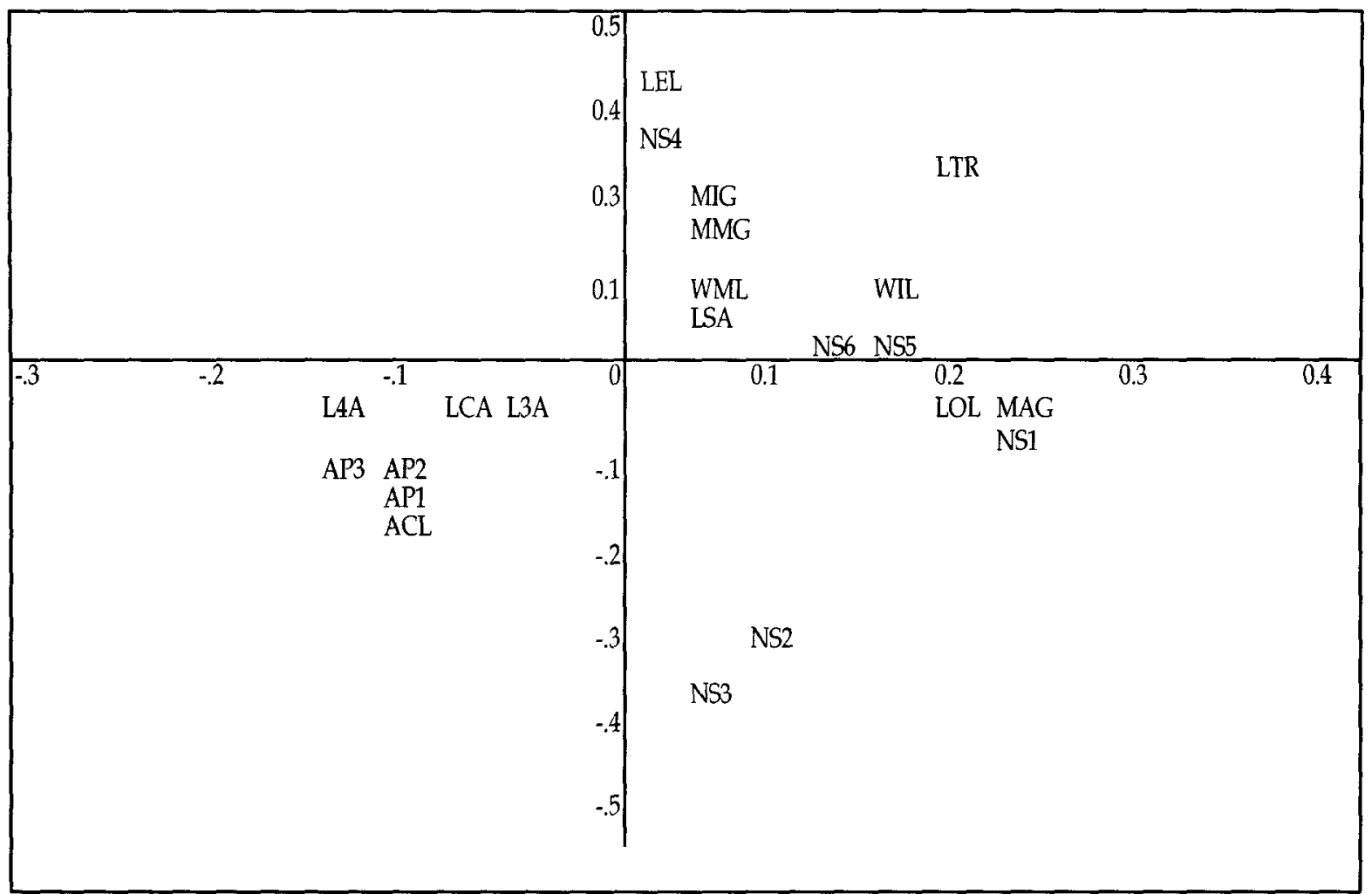

Fig. 1. Principal component analysis using 23 morphological characteristics of $K$. pictus.

Table 4. First three principle components composed of 100 OTUs derived from 23 morphological characteristics

\begin{tabular}{crrr}
\hline Acronym & PC 1 & PC 2 & PC 3 \\
\hline LOL & 0.232 & -0.054 & -0.053 \\
ACL & -0.194 & -0.175 & 0.074 \\
AP1 & -0.187 & -0.136 & 0.065 \\
AP2 & -0.139 & -0.104 & 0.202 \\
AP3 & -0.209 & -0.138 & 0.035 \\
WIL & 0.207 & 0.111 & 0.066 \\
WML & 0.123 & 0.210 & 0.031 \\
WSL & 0.166 & 0.326 & 0.027 \\
LEL & 0.044 & 0.377 & 0.221 \\
LTR & 0.141 & 0.348 & 0.160 \\
LCA & -0.107 & 0.079 & 0.105 \\
LSA & 0.076 & 0.059 & 0.116 \\
L3A & -0.055 & 0.132 & 0.057 \\
LAA & -0.102 & -0.033 & 0.020 \\
MAG & 0.199 & -0.067 & 0.045 \\
MMG & 0.022 & 0.104 & 0.431 \\
MIG & 0.020 & 0.139 & 0.279 \\
NS1 & 0.224 & -0.014 & 0.044 \\
NS2 & 0.109 & -0.303 & 0.344 \\
NS3 & 0.008 & -0.381 & 0.305 \\
NS4 & 0.052 & 0.345 & 0.094 \\
NS5 & 0.170 & 0.059 & 0.042 \\
NS6 & 0.123 & 0.046 & 0.043 \\
Eigen value & 16.197 & 3.345 & 3.083 \\
Proportion of variance & 0.515 & 0.122 & 0.084 \\
Cumulative variance & 0.515 & 0.637 & 0.721 \\
\hline
\end{tabular}

clear separation of the other characteristics.

The cluster analysis (Fig. 2) is concordant with the results obtained from the morphological data. Clustering of K. pictus populations, using UPGMA, was performed based

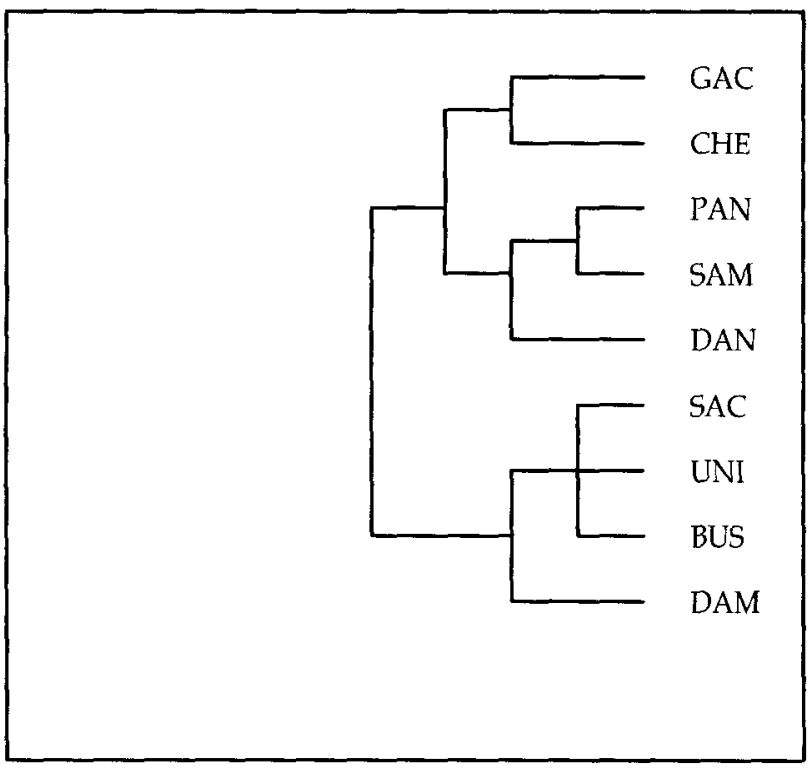

Fig. 2. Correlation phenogram (UPGMA) expressing phenetic similarity of $K$. pictus based on 23 morphological characteristics. 
on morphological characteristics. The dendrogram showed two distinct groups: the northern part of Korea and the southern part of Korea. Many of the morphological characteristics studied among the nine populations were associated with latitude (Fig. 2). For example, the more northern a population group, the less the lobe of leaf but more serrulate at palmatified. However, most morphological variation except LOL and NS is significantly correlated with latitude.

\section{Discussion}

K. pictus has been known for thousands of years as a medicine and vegetative plant. During this time, it has been subjected to selection by man for characteristics that have perfected it as a cultivated crop plant.

The larger number of populations (cultivars) did not differ from each other in most morphological characteristics. However, some morphological characteristics of nine populations were distinct. Although $83.8 \%$ of the total morphological variation was within populations, one of the most striking features of this study was existed a significant difference among populations. The average percentage of morphological differences was $16.2 \%$.

The number of lobe of palmatified leaf, minor groove of palmatified leaf, and length from basal sinus to central lobe apex were those which were considered likely to be useful in the subsequent intensive examination of $K$. pictus (Table 3).

Similar results have already been published on $K$. pictus based on isozyme analysis [5]. They detected a considerable amount of variability within and between the cultivars and natural populations of Korea. In this study morphological characteristics were used to explore the organization of morphological variation within and among nine populations of this species.

In a phylogenetic tree based on morphological variability, the position of the populations in the tree and their geographical position matched almost completely in the populations.

Phenotypic plasticity is an important "buffering" mechanism for individuals in the face of environmental variation when a population has a within gene flow $[8,12]$. Because of the limited number of plants available, phenotypic plasticity could not be assessed quantitatively in the present study. Phenotypic of quantitative traits are subject to environmental influence, $K$. pictus showed the plastic response to environmental variations. The heterogeneous nature of the nine populations, and the low species richness, along with the degree of habitat destruction and fragmentation among populations ought to be an obvious indicator of the need to protect the remaining forest vestiges.

Although $K$. pictus is distributed in a wide geographic range, it is ecologically restricted, growing in high mountains in East Asia. Therefore, local populations are isolated each other, and they are discretely distributed. Furthermore, as discussed above, each local population is subdivided, consisting of many subpopulations. Species with a relatively narrow niche, and with discrete, isolated populations ("habitat specialists") like $K$. pictus in general maintain less genetic variation than do species with continuous, abundant populations growing on broad-niched mainland habitats ("habitat generalists") [10]. This probably implies that the population structure below the local population level may be critical, along with the biological characteristics of the species itself, to determine the level of variation.

The transplanting of materials from the mountains to the lowlands does not greatly aid in the preservation of this narrowly distributed species, but rather it results in the destruction of habitat. Conservation of rare species requires that ecological and genetic factors be considered [9]. Specific environmental conditions, such as a mountain habitat ( 400 to $500 \mathrm{~m}$ above sea level) and very fertile soil, may be of primary importance in the preservation of most populations. Therefore, artificial transplants cannot play a crucial role in determining the conservation of rare or endemic species. Moreover, the degree to which genetic variation is distributed among populations is critical to preserving genetic diversity and the evolutionary potential of a species[2].

In addition, we recommend that a desirable conservation population should be included at least 30 plants per population because high genetic diversity is observed with increasing population sizes (data not shown). It is assumed that if sufficient habitat is maintained to protect against environmental stochasticity, loss of genetic diversity is not an important concern [16]. However, we have failed to detect large actual populations ( $>20$ plants) except nine populations for $K$. pictus examined in this study. Thus, these natural populations are imminent danger of becoming 
extinct if protection is not provided.

\section{References}

1. Antonovics, J. 1968. Evolution in closely adjacent plant populations V. Evolution of self-sterility. Heredity 23, 219238.

2. Hamrick, J. L., M. J. W. Godt and S. L. Sherman-Broyles. 1992. Factors influencing levels of genetic diversity in woody plant species. New Forest 6, 95-124.

3. Huh, M. K. 1999. Genetic diversity and population structure of Korean alder (Alnus japonica Betulaceae). Can. J. For. Res. 29, 1311-1316.

4. Huh, M. K. and H. W. Huh. 2001. Genetic diversity and population structure of wild lentil tare. Crop Sci. 41, 1940-1946.

5. Jung, S. D., H. W. Huh, J. S. Choi, H. H. Chun, K. H. Bang and M. K. Huh. 2003. Genetic diversity and population structure of Kalopanax pictus (Araliaceae). Journal of Plant Biology 46, 255-262.

6. Kim, T. J. 1996. Korean Resources Plants. pp. 169, Seoul National University, Seoul.

7. Lee, Y. N. 1997. Flora of Korea. Kyo-Hak Publishing Co, Seoul, Korea.

3. Morgan, G. G. and D. R. Marshall. 1978. Allozyme uniformity within and variation between races of the colonizing species Xanthium strumarium L. (Noogoura Burr.). Aust. J. Biol. Sci. 31, 283-291.

9. Neel, M. C. and N. C. Ellstrand. 2003. Conservation of genetic diversity in the endangered plant Eriogonum ovalifolium var. vineum (Polygonaceae). Conservationary $\mathrm{Ge}$ netics 4, 337-352.

10. Nevo, E., A. Beiles and R. Ben-Shlomo. 1984. The evolutionary significance of genetic diversity: ecological, demographic and life history correlates, pp. 13-21, In Many G. S. (ed.), Evolutionary Dynamics of Genetic Diversity. Springer, Berlin.

11. SAS Institute Inc:; SAS/STAT User's Guide, Ver, 6, 4th eds. Vol 1. SAS Institute. Cary, 1989.

12. Schlichting, C. 1986. The evolution of phenotypic plasticity in plants. Ann. Rev. Ecol. Syst. 17, 667-693.

13. Silander, J. A. and J. Antonovics. 1979. The genetic basis of the ecological amplitude of Spartina patens. I. Morphologic and physiological traits. Evolution 33, 1114-1127.

14. Sokal, R. R. and F. J. Rohlf. 1981. Biometry. The Principles and Practice of Statistics in Biological Research. pp. 859, 2nd eds., W. H. Freeman and Company, New York.

15. Sun, B. Y., C. H. Kim and W. Y. Soh. 1988. Chromosome numbers of Araliaceae in Korea. Kor. J. Plant Taxonomy 18, 291-296

16. Templeton, A. R. 2002. 'Optimal' randomization strategies when testing the existence of a phylogeographic structure: a reply to Petit and Grivet. Genetics 161, 473-475.

17. Wyatt, R. and S. B. Broyes. 1992. Hybridization in NorthAmerican Asclepias 3. Isozyme evidence. Systematic Botany 17, 640-648.

18. Zar, J. H. 1984. Biostatistical Analysis. pp. 718, 2nd eds., Prentice-Hall. Englewood Cliffs, New Jersey.

\title{
초록 : 한국 음나무(두롭과) 집단의 형태적 분석
}

\author{
정상덕* $\cdot$ 홍정희 $\cdot$ 방경환 $^{1} \cdot$ 허만규 $^{2}$ \\ (부산대학교 생물학과, ${ }^{1}$ 농촌진홍원 인삼약초과, ${ }^{2}$ 동의대학교 분자생물학과)
}

한국내 분포하는 음나무(Kalopanox pictus Nakai)의 집단간 분화를 연구하기 위해 형태적 특성을 조사하였다. 23개 형테 형질에 근거하여 지역간 분화는 현저하였다. 아흡 집단에서 138 표본으로 유효한 분류학적 단위(OTU) 를 표현형 유사도와 형태적 변이를 조사하였으며 주성분 분석을 실시하였다. 첫 세 주성분 요소가 전체 변이의 $77.0 \%$ 에 관련이 있었다. 이 중 첫 번째 주성분 요소가 전체 변이의 $52 \%$ 에 기여하였는데 이에 해당되는 형질은 장상복엽의 장상렬의 수, 그리고 장상렬의 폭이다. 형태적 변이에 근거한 군집분석에서 우리나라 남부와 중부지 방의 두 그룹으로 나누어졌다. 